\title{
UPPER LAYER CIRCULATION IN THE BANDA SEA IN RESPONSE TO THE ONSET OF MONSOON WINDS
}

\author{
by
}

\author{
W. HUTAHAEAN ${ }^{1}$ and R.E. WILSON ${ }^{2)}$
}

\begin{abstract}
Aspects of the upper layer circulation in the interior of the Banda Sea, Indonesia, associated with local forcing by monsoon winds are examined numerically through the use of a reduced gravity model. The basin is located between approximately $4^{\circ} \mathrm{S}$ and $8^{\circ} \mathrm{S}$ and is partially enclosed by chains of islands. The primary emphasis is an evaluation of the free wave response which contributes to the steady or slowly varying circulation. Basin response appears to be characterized by interacting Kelvin waves and Rossby at low frequencies, and by evanescent Poincare waves of higher frequencies. Passages between islands along the perimeter of the basin appear to be nearly, impermeable to Rossby waves, which contribute to a pattern of westward propagating quasi geostrophic eddies. This pattern would persist during periods of wind transition.
\end{abstract}

\section{ABSTRAK}

Aspek-aspek sirkulasi lapisan atas di Laut Banda, Indonesia yang disebabkan oleh angin monsoon dianalisa secara numeris dengan menggunakan model "gravitasi terkurang' (reduced gravity). Basin ini berada diantara $4^{\circ} \mathrm{S}$ dan $8^{\circ} \mathrm{S}$ dan dikelilingi oleh rantaian pulau-pulau. Penekanan utama adalah evaluasi tanggapan gelombang bebas yang berperan dalam sirkulasi tunak (steady circulation) atau sirkulasi yang berubah secara perlahan. Tanggapan basin kelihatannya dicirikan oleh gelombanggelombang Kelbin yang berinteraksi dengan gelombang-gelombang Rossby pada frekwensi rendah, dan gelombang-gelombang Poincare yang mengecil dengan cepat pada frekwensi tinggi. Selat-selat (passage) diantara pulau-pulau di sekeliling basin tampaknya tidak dapat dilewati (impermeable) oleh gelombang-gelombang Rossby, dan menghasilkan rambatan quasigeostropik eddi ke arah barat. Pola ini juga terlihat pada saat pancaroba.

\section{INTRODUCTION}

The Banda Sea is located in the eastern Indonesian Archipelago, between approximately $4^{\circ} \mathrm{S}$ and $8^{\circ} \mathrm{S}$. It is a very deep basin partially enclosed by chain of islands (Figure 1). The basin is approximately $900 \mathrm{~km}$ long and $500 \mathrm{~km}$ wide; the maximum depth is nearly $7400 \mathrm{~m}$.

1) Research and Development Centre for Oceanology-LIPI, Ambon, Indonesia.

2) Marine Sciences Research Center, SUNY at Stony Brook, N.Y. 11794-5000, U.S.A. 


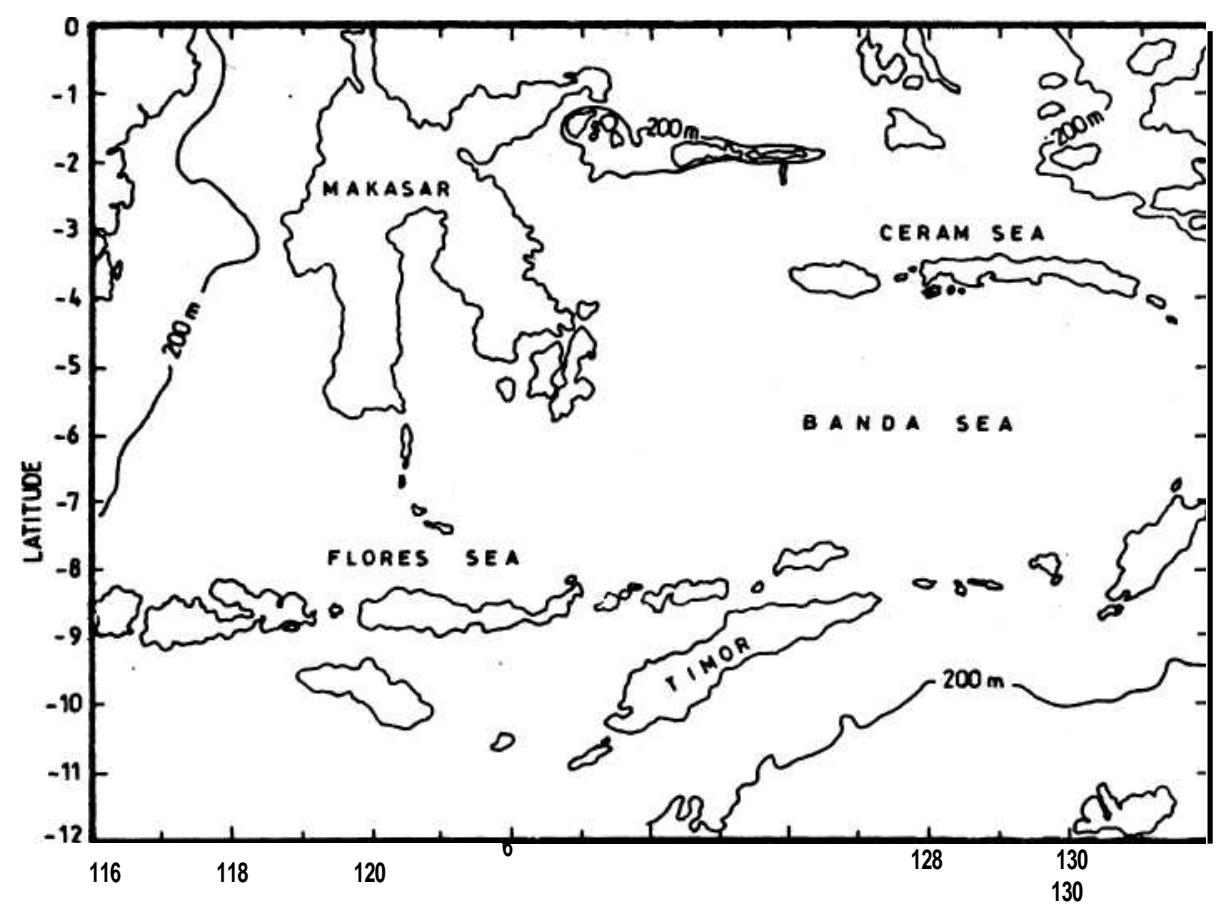

Figure 1. The Banda Sea study region

\section{The Banda Sea study region.}

Southeast Asian monsoon dominates the large-scale meteorological forcing. Strong east winds blow across the archipelago from May ti early September, and west winds from November to March. Winds are very steady with characteristic speeds from 6 to 10 $\mathrm{ms}^{-1}$ (WYRTKI, 1961). During transition periods, the wind is weak and variable. Knowledge of the circulation in this region is primarily from studiesby WYRTKI (1961, 1987). Wyrtki recognized that monsson winds produce a direct locally forced response, as well as fluctuations in the persistent flow from Pacific to Indian Oceans through the Indonesian archipelago associated with the Pacific-Indian Ocean pressure gradient.

RAO (1966), have described free wave motion in a uniformly rotating basin. He has shown that the excited waves are of Kelbin-type and that these waves are progessively more trapped along the boundary as the rate of rotation increases. Previous studies of motions in non uniformly rotating closed basin have shown that the baroclinic oscillations are confined to the response adjustment to the boundaries (RATTRAY and CHARNELL, 1966). 
The oscillations are two distinct of types : gravity waves which are either dynamically similar to Kelvin waves or Poincare waves and Rossby waves (MOFJELD and RATTRAY, 1971). The importance of Rossby waves in the adjustment processes has been pointed out by LIGHTHILL (1969), and the interplay of Kelvin waves and Rossby waves have been described in more detail CANE and SARACHIC (1976) in low latitude ocean.

In this paper we will examine some of the characteristics of the upper layer circulation in the interior of the Banda Sea produced by the local wind forcing associated with monsoon winds. The focus of our study is an evaluation of the free waves response which contributes to the steady or slowly varying circulation. Effects of the iarga scale pressure gradient between the Pacific Ocean and Indian Ocean and the important effects of advection of water with distinct temperature and salinity characteristics into the basin (i.e., low salinity water entering from the Flores Sea) are not considered.

Numerical results for wind induced motion in the Banda Sea was interpreted in the light of the previous results for wave motions in uniformly and non uniformly rotating basins.

\section{BRIEF DESCRIPTION OF THE MODEL}

In this study we use a reduced gravity model which can incorporate a variable Coriolis parameter. The model is based on the following equations,

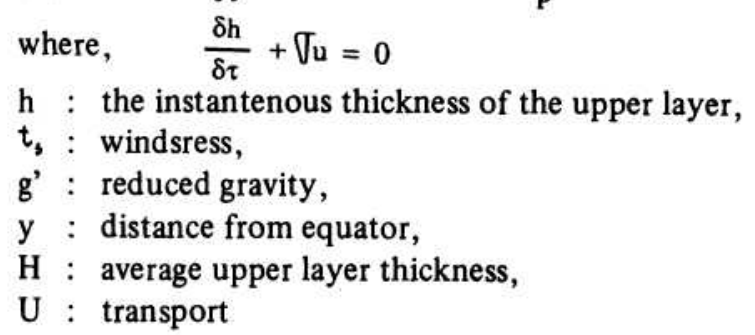

The average upper layer thickness is choses to be $200 \mathrm{~m}$. A density difference $\mathrm{xxxx}$ of $0.005 \mathrm{kgm}$ is specified. As discussed below, a simplified rectangular basin configuration is first considered; then a more realistic basin configuration is introduced which is determined from the $200 \mathrm{~m}$ bathymetric contour from the Snellius-Expedition (1927) survey.

Equations (1) are solved numerically based on KOUTITONSKY et al, (1987). The extended study area has a $44 \times 24$ finite difference mesh. The equation of motion is integrated in time using a leapfrog finite difference scheme. The model time step is approximately 1 hour. The size of the grid is $30 \mathrm{~km}$ which is chosen to be significantly smaller than the internal Rossby radius $(170 \mathrm{~km})$. Since the fluid model is inViscid, 


\section{HUTAHAEAN \& WILSON}

we apply the free slip condition at the solid boundaries.

An ORLANSKI (1976) radiation boundary condition is imposed at passages to allow the gravity waves and Rossby waves to be radiated out from the interior of the domain.

The model was started from rest and forced by an impulsive uniform wind stress with a value of 1.5 dyne $\mathrm{cm}^{\prime 2}$. Winds are applied for 3 months until a approximate oscillatory steady state was achieved, and then allowed to relax. Simulations were continued long enough so that the resulting free wave motion could be described through spectral analysis.

\section{RESULTS AND DISCUSSION}

Here we present results for the response of a bounded and partially bounded rotating basin to impulsive wind forcing. The basin scales are chosen to be characteristic of the Banda Sea. Because of the complexity of wave motion in a basin at this latitude, our strategy is to describe first the response of a bounded uniformly rotating rectangular basin, second, the response of a bounded basin with non uniformly rotation, and third the response of a partially bounded basin.

\section{The bounded uniformly rotating basin.}

Examples of transport vectors and layer thickness deviation are shown in Figure 2. Strong free wave motion dominates the response even during active wind forcing. The pattern precess about the basin in a clockwise and show clear evidence of basinwide gravity wave motion.

Spectral analysis applied, for example, to a time series for components of velocity at a point in the basin (Figure 3) can provide insight into the types of gravity wave motion present. Distinct peaks appear at approximately 12.8 days, 4.8 days, 3.8 days and 3.2 days in the spectrum for east-west component. An especially strong peak at 3.8 days appears in the spectrum for the north-south component. These spectral peaks can be compared to the inertial period which is 5.7 days and to the lowest seiche mode of 11.7 days as determined by the relation (Rao, 1966) :

$$
v \tau 1=\pi c\left(\frac{\mathrm{K}^{2}}{\mathrm{~L}^{2}}+\frac{\mathrm{C}^{2}}{\mathrm{~W}^{2}}\right)^{1 / 2} ; \mathrm{k}, 1=0,1,2, \ldots
$$

where $v$ are seiche frequencies, $c^{2}=g^{\prime} H, L=1320 \mathrm{~km}$, and $W=720 \mathrm{~km}$. 
Upper layer circulation
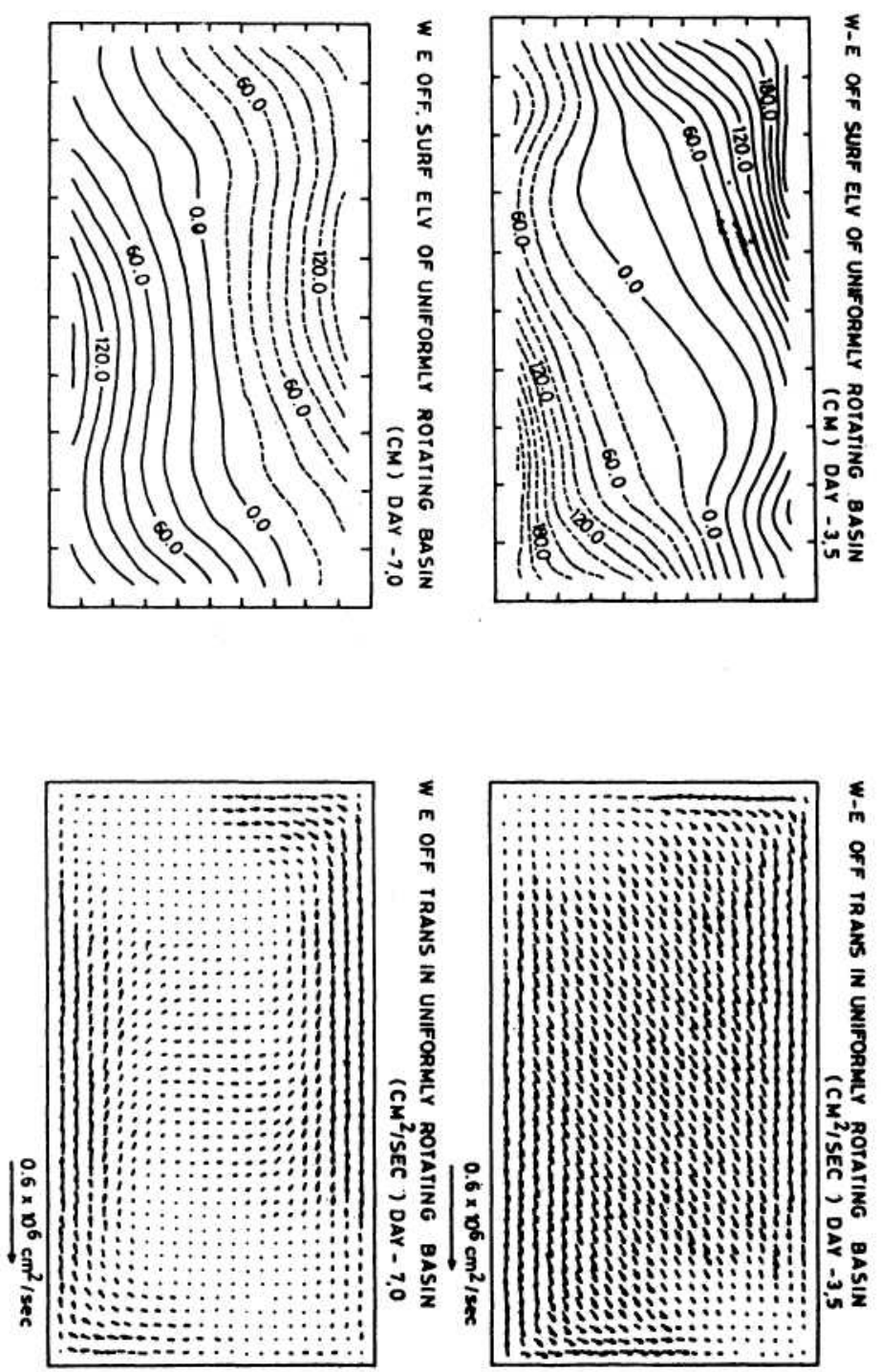

Figure 2. Layer thickness deviation (cm) and transport $\left(\mathrm{cm}^{2} / \mathrm{s}\right)$ in a rectangular bounded basin for 3.5 and 7.0 days after relaxation of wind. Basin parameters are length, $L=1320 \mathrm{~km}$, and wide, $\mathrm{W}=$ $720 \mathrm{~km}$. The Coriolis parameter $f=1.27 \times 10^{-5} / \mathrm{s}$ is constant. 


\section{HUTAHAEAN \& WLSON}
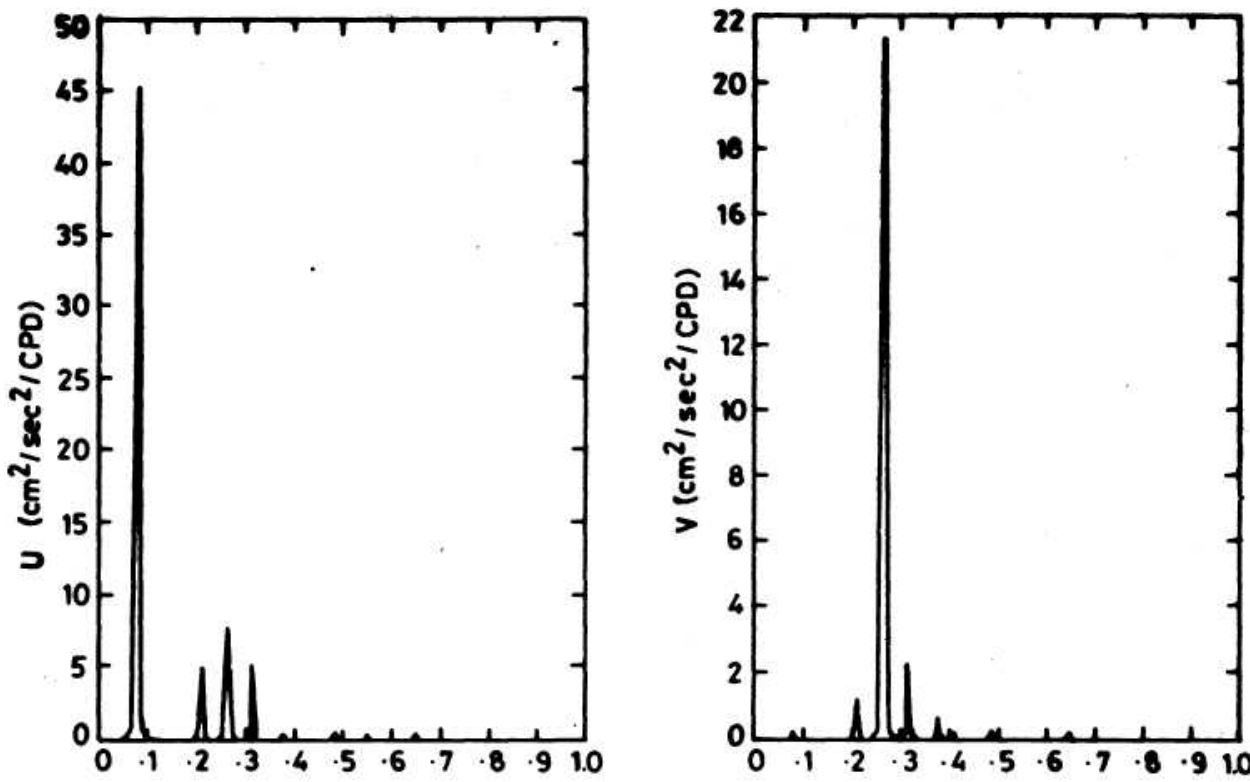

FREQUENCY (CPD)

FREQUENCY (CPO)

Figure 3. The spectral density of velocity components (east-west component $U_{2}$, northsouth component V2) at an interior point of the basin whose parameters were described in Figure 2. Bandwidht $=2 \times 10^{-3} / \mathrm{d}$.

The general effect of rotation on the excited gravity waves in a basin is to split the gravity waves at the seiche frequencies, producing lower frequency Kelvin-type motion and higher frequency Poincare-type motion. In our basin the ratio of the lowest seiche period to the inertial period (also the ratio of basin scale to internal Rossby radius) is approximately 2.0 which implies moderate rotation.

The spectral peak at 12.8 days (Figure 3 ) represents motion with a period intermediate between the lowest seiche mode and the lowest Kelvin mode which is approximately 18 days. The high frequency peaks represent superinertial Poincare waves. For stronger rotation the splitting would be stronger and the low frequency peak would approach the lowest Kelvin mode.

The phenomenon of splitting at the seiche frequency upon the intriduction of rotation has been described by various authors including LAMB (1945), TAYLOR (1922), and RAO (1966). We can compare our results with those obtained by RAO (1966), who using a method formulated by PROUDMAN (1916) computed numerically the split frequencies for a restangular basin. By adopting his results for a rect. angular basin to a basin of our scale and rotation rate $\left(\frac{f}{b_{10}}=2.0\right.$. were $f$ is Coriolis coefficient and $\mathrm{xx}$ is the lowest mode for a non rotating basin), we can see clearly how the seiche modes (Table $1 \mathrm{~b}$ ) are split (Table 1a). For a rotating basin the excited frequencies are all shifted to higher value, except in $\sigma_{10}$ and $\sigma_{20}$ modes which shift ot lower frequences. 


\section{Upper layer circulation}

Table 1a. Frequencies and periods of modes for $\mathbf{x x x}=2.0$.

Basin parameters area; length, $L=1320 \mathrm{~km}$, and width, $W=720 \mathrm{~km}$.

$\begin{array}{cccccc}\text { Mode } & \sigma\left(10^{-6} \mathrm{~S}^{-1}\right) & \mathrm{T} \text { (days) } & \text { Mode } & \sigma\left(10^{-6} \mathrm{~S}^{-1}\right) & \mathrm{T} \text { (days) } \\ (1,0) & 5.442 & 13.4 & (2,0) & 10.636 & 6,8 \\ (0,1) & 15.043 & 4.8 & (1,1) & 18.390 & 3.8 \\ (2,1) & 19.037 & 3.8 & (3,1) & 23.000 & 3.2 \\ (3,0) & 22.568 & 3.2 & (0,2) & 27.032 & 2.7 \\ (1,2) & 27.464 & 2.6 & (4,0) & 22.536 & 3.2\end{array}$

Table 1b. Frequencies and periods of modes for non rotating basin. Basin parameters were described in Table 1a.

$\begin{array}{lccccc}\text { Mode } & \sigma\left(10^{-6} \mathrm{~S}^{-1}\right) & \mathrm{T} \text { (days) } & \text { Mode } & \sigma\left(10^{-6} \mathrm{~S}^{-1}\right) & \mathrm{T} \text { (days) } \\ (1,0) & 6.212 & 11.7 & (2,0) & 12.424 & 5.9 \\ (0,1) & 11.388 & 6.4 & (1,1) & 12.972 & 5.6 \\ (2,1) & 16.853 & 4.3 & (3,1) & 21.840 & 3.3 \\ (3,0) & 18.635 & 3.2 & (0,2) & .22 .777 & 3.2 \\ (1,2) & 23.608 & 3.1 & (4,0) & 24.847 & 2.9\end{array}$
shift up.

There is general tendency for subinertial to shift down and for superinertial to

We identify our 12.8 days peak with $\sigma_{10}$ and our strong 3.8 days peak with $\sigma_{21}$ The especially strong oscillation of the north-south component of velocity at 3.8 days peak would be associated with motion parallel to the crest of a Poincare wave.

We notice that there is no inertial period present. Since the width of the basin is about four times the Rossby radius of deformation, the overlapping Kelvin-type waves which propagate in opposits directions at the northern and southern boundaries could produce a significant pressure gradient across the basin and upset the balance between local acceleration and the Coriolis force.

Examples of transport and layer thickness deviation (Figure 4) indicate complex patterns of wave motion. In addition to basin-wide gravity wave motion, there is ividence for strong short wavelength Rossby wave motion in the region of western boundary. The relationship between transport and layer thickness deviation suggest that this motion is quasi geostrophic.

Spectrum for the velocity components (Figure 5) indicate the presence of very low frequency motion; distinct peaks occur at approximately 80 days and longer 
HUTAHAEAN \& WILSON

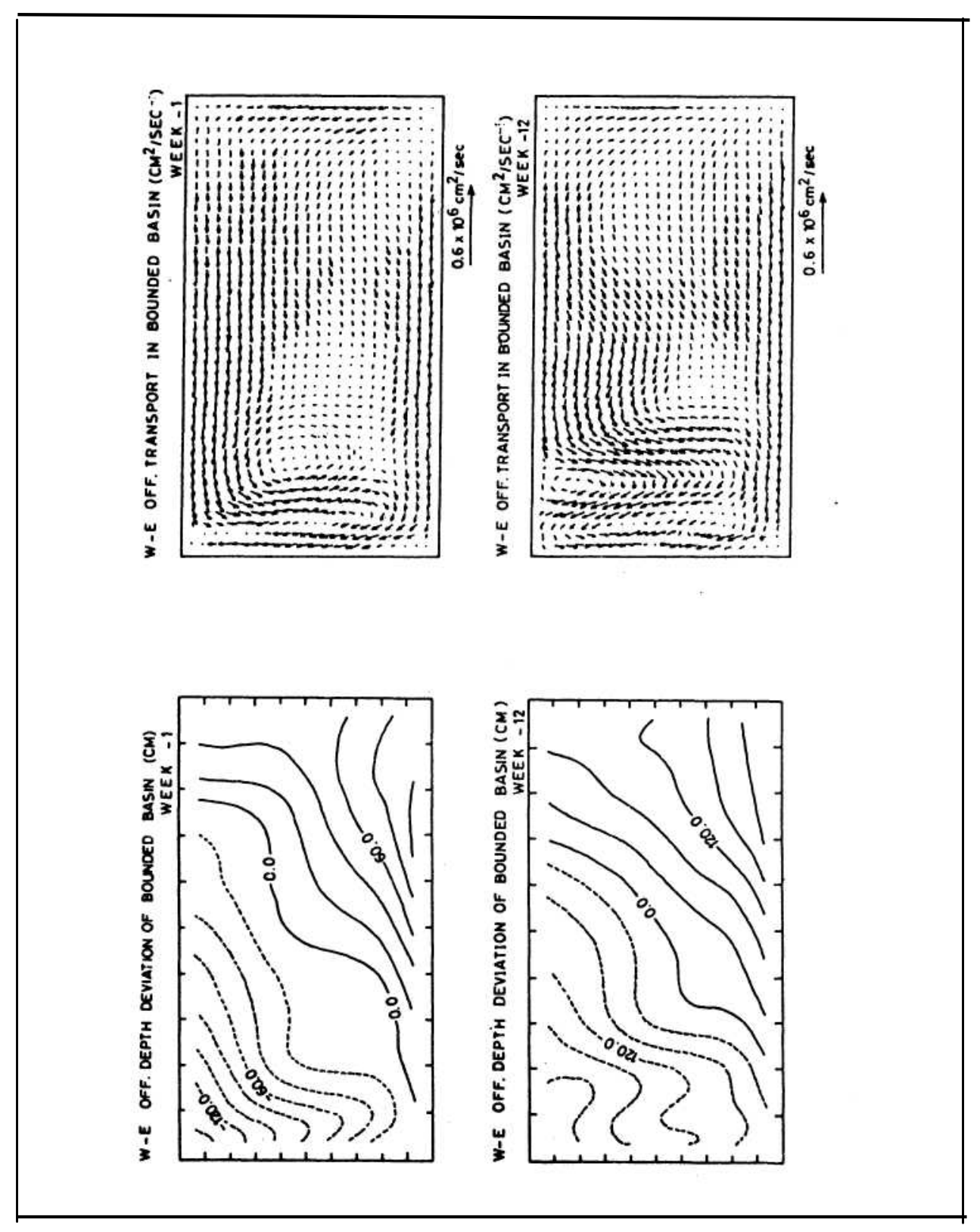

Figure 4. Layer thickness deviation $(\mathrm{cm})$ and transport $(\mathrm{cm} / \mathrm{s})$ in a rectangular bounded basin for week 1 and 12 after relaxation of wind. Basin parameters are length, $\mathrm{L}-1320 \mathrm{~km}$. and wide, $\mathrm{W}-720 \mathrm{~km} \mathrm{~km}$. The Coriolis parameter is $\mathrm{f}=\beta \mathrm{y}$, where $\beta=2.3 \times 10^{-11} / \mathrm{s}$. 
Upper layer circulation

days. Spectra also indicate the presence of wave motion with a period of 28 days and 7.6 days.

An estimate of the range of frequencies which we might expect is available from the dispersion relation for quasigeostrophic free oxcillations id a clozed basin of limited meridional extent (on a $\beta$-plane) subject to non uniform rotation as given by Mofjeld and Rattray (1971).

$$
V_{m n}=-\frac{\beta}{2 \pi\left(\frac{m^{2}}{L^{2}}+\frac{n^{2}}{W^{2}}\right)} ; m, n=1,2, \ldots
$$

where $v_{\operatorname{man}}$ are the excited frequencies, $\beta$ is the rate of change of Coriolis parameter with latitude, and $\mathrm{L}$ and $\mathrm{W}$ are basin dimensions. Relaxation of this assumption gives lower frequencies for each mode than expressed by (3). From (3), we obtain a period of 31 days for the first mode $v_{11}$; higher modes have longer periods. Mode $v_{44}$, for example, has period of 125 days. We interpret our very low frequency motion in terms of a contribution from basin-wide Rossby waves.

A more realistic dynamical interpretation for motion in non uniformly rotating basin has been outlined by Mofjeld and Rattray (1971) and Cane and Sarachik (1979).

They have pointed out that the response will involve the interplay pf Kelvin-type motion and Rossby waves. To discuss this interaction, we will derive briefly the dispersion relationship. For free waves, (1) could be reduced to a single evation for $\mathrm{V}$, the north-south component of transport.

$$
\frac{\delta v}{\delta \tau}\left(\frac{1}{C^{2}}\left(\frac{\delta^{2} v}{\delta \tau^{2}}+F^{2} v\right)-\left(\frac{\delta^{2} v}{\delta x^{2}}+\frac{\delta^{2} v}{\delta y^{2}}\right)\right)-\beta \frac{\delta v}{\delta x}=0
$$

For solutions proportional to

$$
\mathrm{e}^{\mathrm{i} K R \cdot \mathrm{im}} \text { reduces to ordinary diferential equation }
$$

$$
\frac{d^{2} v}{d x^{2}}+\left(\frac{W^{2}}{C^{2}}-\kappa^{2}-\frac{\beta \kappa}{W}-\frac{\beta^{2} y^{2}}{C^{2}}\right) v=0
$$

subject to the conditions at the northern and souther boundaries

$$
\mathbf{V}=\mathbf{0}
$$

From (7) we obtain a dispersion relation

$$
(w / c)^{2}-\kappa^{2}-\beta^{k} / w=(2 \mu+1) \beta / C
$$

Cane and Sarachik (1979) have computed the eigenvalue $\mu$ numerically and analytically. Their results show that the eigenvalue $\mu$ dan be approximately by an integer for the first three lowest modes.

For small ( $w / c)^{2}$ and $k$ (long waves), the dispersion relation takes a simple form 
(9)

$$
(w /)_{k}=-C(2 \mu+1)
$$

which is a nondispersive wave. These waves move in the direction opposite (westward) to the Kelvin wave (along the northern boundary) with a speed reduced by a factor of $2 \mu+1$. With this wave speed, the time needed by the Rossby wave to cross the model basin is 17.6 days. We can identify the period of 28 days period of oscillation (Figure 5) as the time needed by a Kelvin wave to propagate across the basin plus time for its reflection as a long Rossby wave to propagate back to the west.

For shorter waves, the group velocity is eastward. The maximum value is,

$$
\mathrm{Cg}=\frac{\mathrm{c}}{8\left(2^{\prime}+1\right)} \quad \text { When } \mathrm{k}==\cdot[3(2 \mu+1) \beta / \mathrm{C}]^{1 / 2}
$$

When $\mu=1$, for example, this corresponds to a time nearly 168 days to cross the basin; a reflected Kelvin wave would then propagate along the wouthern boundary. Hence the total travel time to cross the basin for shorter Rossby wave plus Kelvin wave is approximately 175 days. We then interpret the low frequency spectral peaks in term of this type of combined Rossby wave and Kelvin-type motion.
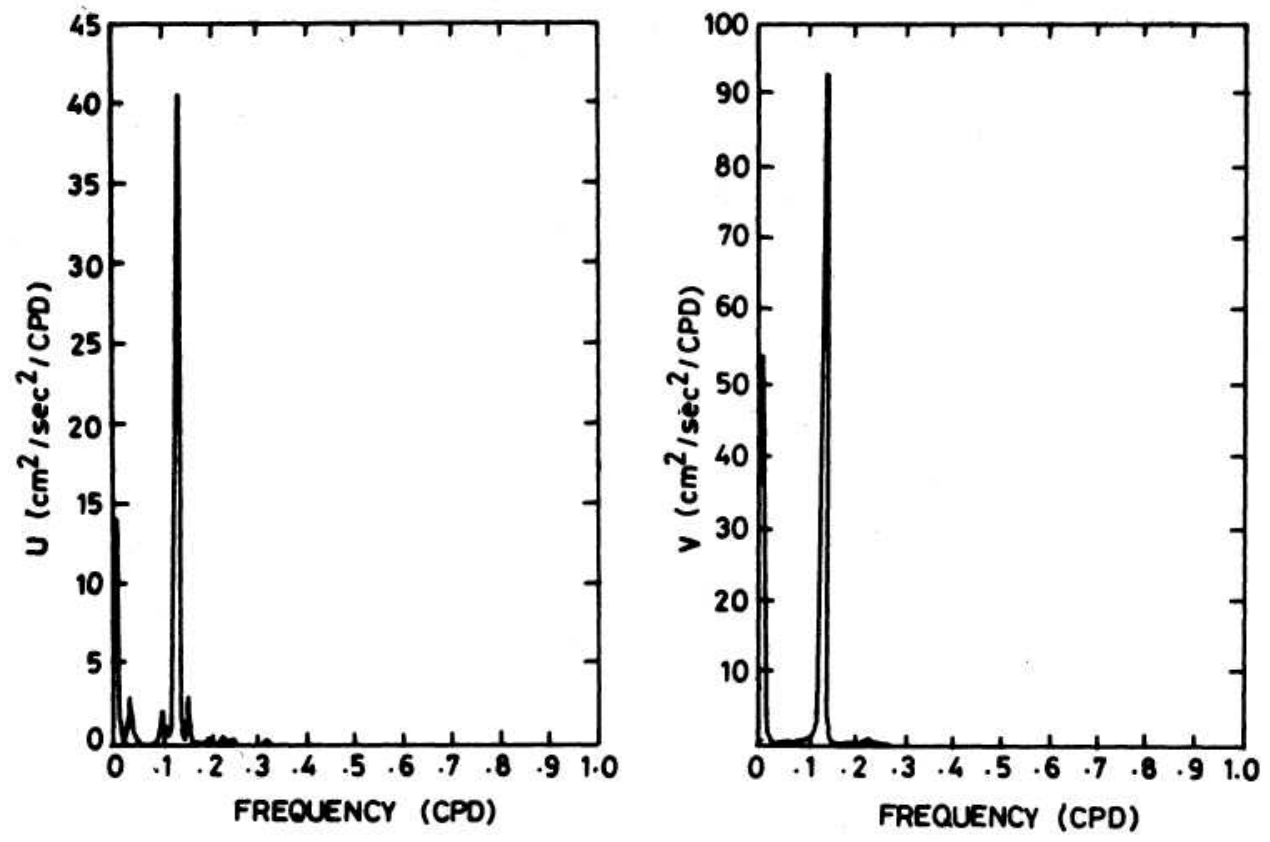

Figure 5. The spectral density of velocity components (east-west component U2, north-south component V2) at an interior point of the non uniformly rotating basin. Basin parameters were described if Figure 4. Bandwidth = $2 \times 10^{-3} / \mathrm{d}$. 
Upper layer circulation

The 7.6 days spectral peak which is especially strong for the north-south velocity component could be interpreted in term of Poincare waves. In our non uniformly rotating basin the local inertial period varies from approximately 14 days to 4 days. We therefore attribute this spectral peaks to evanescent Poincare waves trapped along the northern boundary of the basin.

We can, hencefore, summarize that the basin response in terms of oscillation which consist of combination of planetary waves and lower mode of gravity waves

\section{The partially confined non uniformly rotating basin}

In this section, we examine some aspects of response to the onset of winds in a partially confined basin. Numerical experiments were conducted to evaluate the influence of a passage of a different width and position in the perimeter of the domain on the characteristics of wave motion in the interior.

In light of previous result (Me Kee, 1972) on the scattering of Rossby waves near a gap, we expected that our gaps would be -essentially impermeable to basin scale Rossby waves. We expected this to be true as long as gap width was significantly less than the wavelength of the incoming waves. Results of our experiments seem to confirm this suggestion. The most definitive results (Figure 6) was that gaps of the order of one Rossby radius in width (short period gravity waves) is in order, especially if the gaps was positioned contiguous to a left bounded corner.

We conclude that Kelvin-type waves do radiate from the basin through the gaps of the order of one larger Rossby radius wide, and that basin scale Rossby do not. The low frequency basin scale quasigeostrophic motion could be expected to persist long after the wind has relaxed. Because the Kelvin waves appear to interact with the Rossby waves, the gaps affect the Rossby waves if only indirectly.

Example of the results for simulation which incorporate a more realistic basin configuration characteristic of the Banda Sea (Figure 7) including gaps in the eastern and western perimeter are shown in Figure 8. These results emphasize the initial Kelvin wave radiation: from the basin and the persistent low frequency basin scale Rossby wave motion. This motion is characterized by quasigeostrophic eddies which tend to propagate westward. Certain aspects of this flow pattern agree with the flow described by Wyrtki (1961), particularly during the transitional period in April. 


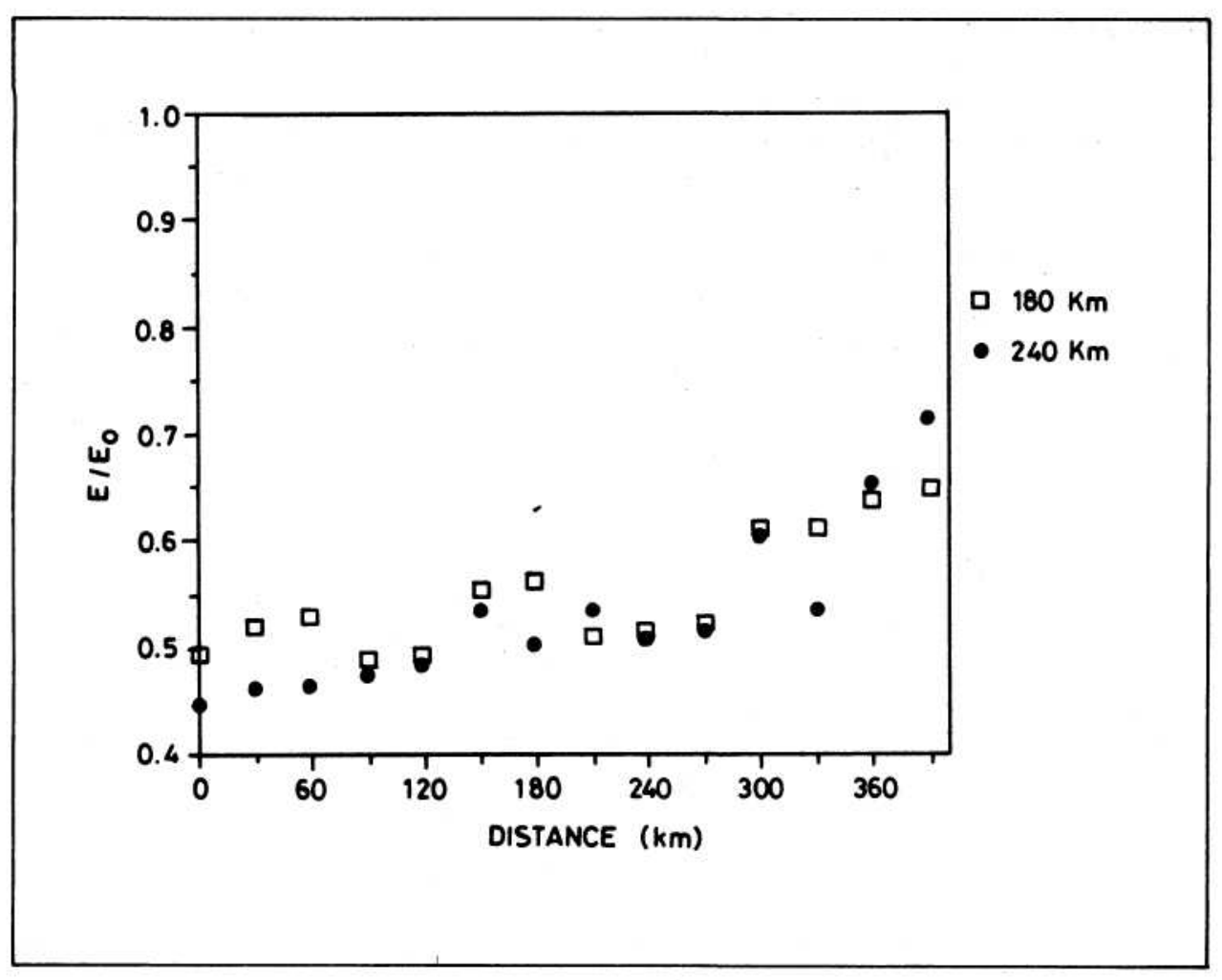

Figure 6. Energy ratio in rectangular partially confined basin with a gap in the perimeter as a function of gap width and distance of gap from a bounded corner. Eo is initial of total energy upon opening the gap, and $E$ is final of total energy after 500 days. 

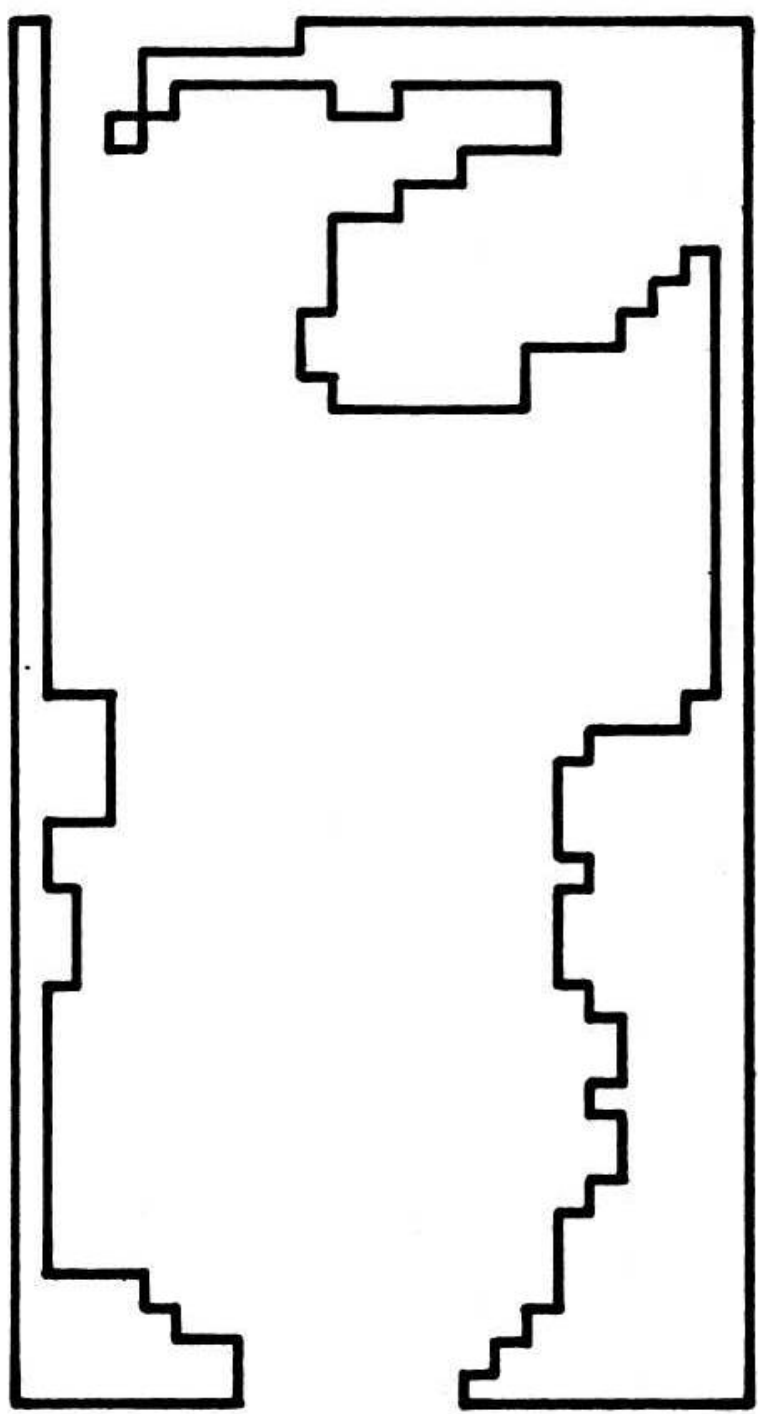

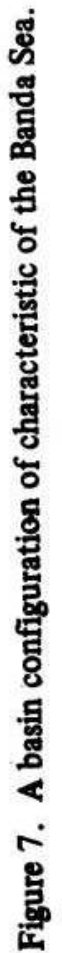


HUTAHAEAN \& WILSON

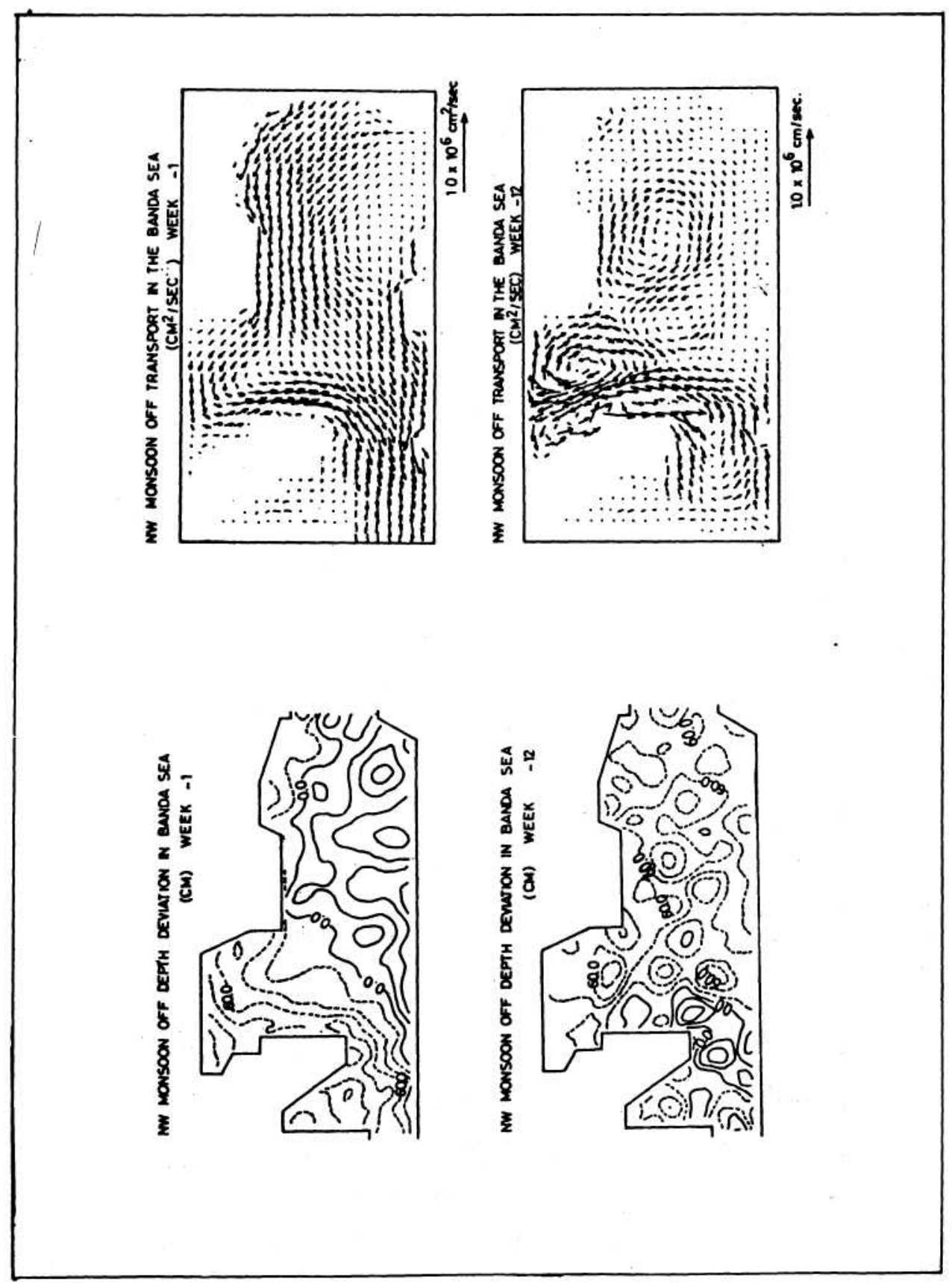

Figure 8. Layer thickness deviation $(\mathrm{cm})$ and transport $\left(\mathrm{cm}^{2} / \mathrm{s}\right)$ in the Banda Sea for weeks 1 and 12 after relaxation of winds. 
Upper layer circulation

CONCLUSION

The free wave motion in the Banda Sea is characterized by a very strong Rossby wave motion interacting with Kelvin waves. We also expect strong evanescent Poincare waves motion.

Passages in the eastern and western boundaries do not appear to affect the low frequency Rossby wave motion within the basin directly. Their motion should persist even after relaxation of winds through the monsoon transition periods. It is characterized by westward propagating quasigeostrophic eddies, and could contribute to strong currents along the east coast of Sulawesi Island.

\section{REFERENCES}

CANE, MA and E.S. SARACH1K, 1979. Forced baroclinic ocean motions, 111 : The linear equatorial basin. J. Mar. Res., 37 (2) : 335-398.

KOUT1TONSKY, V.G. et.al, 1987. "SWK3D" : An Enhanced version of the VANERN three-dimensional hydrodynamical model for applications to a stratified semienclosed seas. A Report for the Canadian Hydrographic Service. Maurice Lamontagne Inst., Pomte-aux-Cenelles, Oc, G5H 324.

LAMB, H 1945. Hydrodynamics, $6^{\text {th }}$ ed. Dover.

LIGHTHILL, MX, 1969. Dynamic response of the Indian Ocean to the onset of the Southwest Monsoon. Phil. Trans. Roy. Soc. Lpndon, A 265 : 45-92.

MC KEE, W.O., 1972. Scattering of Rossby waves by partial barriers. Geophys. Fluid Dynamics, $4: 83-89$.

MOFJELD, HI. and M. RATTRAY, JR., 1971. Free oscillations in a beta-plane ocean. J. Mar. Res., 29 (3) : 281-305.

ORLANSK1, L, 1976. A simple boundary condition for unbounded hyperbolyc flows. J. Computational Physics, 21 : 251-261.

PROUDMAN, J., 1916. On the dynamical theory of tides. Part 11. Flat seas. Proc. Lond. math. Soc, ( $2^{\text {nd }}$ Serices), $18: 21-35$.

RAO, D.B., 1966. Free gravitational oscillations in rotating rectangular basins. J. Fluid Mech., 25 (3) : 523-555.

RATTRAY, JR., M. and R.L CHARNELL, 1966. Quasigeostrophic free oscillations in enclosed basin. J. Mar. Res., 24 (1) : 82-102.

TAYLOR, GJ., 1922. Tidal oscillations in gulf and rectangular basins. Proc. Lond. Math. Soc, 20 : 148-181.

WYRTKi, K., 1961. Physical Oceanography of the Southeast Asian Waters. NAGA Report No. 2 (Scripps Institute of Oceanography, Washington DC).

WYRTKI, K., 1987. Indonesian throughflow and the associated pressure gradient. J. Geophys. Res., 92 (C12) : 12941-12946. 